\title{
SHEVIRAT HA-KELIM: JEWISH MYSTICISM AND THE CATALAN MATRIX FOR DIALOGUE AND CONFLICT
}

\author{
Mario Macías \\ (Institute of Law and Technology, Universitat Autònoma de Barcelona) \\ mario.macias@uab.cat \\ Pompeu Casanovas \\ (Institute of Law and Technology, Universitat Autònoma de Barcelona; LawTech Research Group, La Trobe Law School, La \\ Trobe University, Melbourne, Australia) \\ pompeu.casanovas@uab.cat p.casanovasromeu@latrobe.edu.au \\ John Zeleznikow (iD) \\ (La Trobe Law School, La Trobe University, Melbourne, Australia) \\ J.Zeleznikow@latrobe.edu.au
}

\begin{abstract}
Late Medieval anti-Jewish violence is a well-known phenomenon, but its origins and especially its institutionalization are still blurred and enigmatic. In $13^{\text {th }}$ and $14^{\text {th }} \mathrm{c}$. Catalonia, the denouement of the increasing popular hostility against the Jewry was particularly dramatic. The seeds of violence were the result of a long and complex process of social, theological, and political interactions. In this contribution, we will discuss the intellectual matrix of medieval anti-Semitism in Catalonia and its relationship with the rising of scholastics and with the theoretical foundations of Catalan politics. We will also approach its counterpart: the Jewish response to collective suffering.
\end{abstract}

Keywords: Medieval Catalonia, anti-Jewish violence, Scholastics, Jewish mysticism

\footnotetext{
Acknowledgements: Project IEC PRO2018-S05. Models del dret i la filosofia política catalanes: semàntica de les doctrines juridicopolítiques del pactisme en les seves diferents fases [Models of Catalan political philosophy and law: semantics of pactmodel driven political and legal doctrines at their different stages].

Disclosure statement: No potential conflict of interest was reported by the authors.

License: This work is under Attribution-NonCommercial-NoDerivs 3.0 Unported (CC BY-NC-ND 3.0)

http://creativecommons.org/licenses/by-nc-nd/3.0/

Suggested citation: Macías, M., Casanovas, P., Zeleznikow, J. (2019-2020). "Shevirat Ha-Kelim: Jewish Mysticism and the Catalan Matrix for Dialogue and Conflict", Journal of Catalan Intellectual History 12: 64-96 DOI: 10.2478/jocih-2019-0005
} 


\section{INTRODUCTION}

Let' start with a comment by Clive S. Lewis (1964: 211), also quoted by Anthony Bonner (2012: 334) in his last book about the logic and art of Ramon Llull:

If you had asked Lazamon or Chaucer 'Why do you not make up a brand-new story of your own?' I think they might have replied (in effect) 'Surely we are not yet reduced to that?' Spin something out of one's own head when the world teems with so many noble deeds, wholesome examples, pitiful tragedies, strange adventures, and merry jests which have never yet been set forth quite so well as they deserve? The originality which we regard as a sign of wealth might have seemed to them a confession of poverty.

Lewis shed light on the common organon that conformed the medieval thinking, the distance that separates our modern understanding from it, and the intellectual ways to represent and overcome such a distance.

This paper is an essay on violence, poetry, resilience and cultural transmission. We should avoid falling into the Platonism of cultural structures and talking about archetypes, ages, parameters, paradigms, epistemes or eons. If used, they might be considered just as a stool over which we can stand up and look further, or as a mere scaffold of our language to collect and classify information, to formulate hypotheses about their relations and dynamics. We conceive intellectual history as a toolkit for which we invent rules of usage in order to achieve a reviewable knowledge, rather than an ensemble of consolidated theses to ground certainty.

Concepts embedded and settled on narrations, tales, poems and religious invocations can also be conceived as a cognitive technology: they are natural tools to manipulate the surrounding reality, to make it easier to perceive and to act upon it. As shown by scholars of ancient literature and philosophy such as Lovejoy and Lewis, we cannot take for granted that our reading matches their inception. Concepts and underlying models of knowledge have the property of molding regulatory cultural identities changing over time, but with recognizable boundaries. Medieval minds loved the production of order. We can track them even if "what is truly the rim seems to us the hub" (Lewis 1964: 58).

\section{THE JEWISH KABBALAH}

Kabbalah [ has always been present in Jewish theology, but not all the mystical movements can be considered Kabbalah. Sometimes, the theoretical distinctions are too subtle and inconclusive. According to Jewish tradition, Kabbalah has been practiced since the Roman occupation, a belief that has been historically nourished using pseudo-epigraphs to increase the value of modern works. The intellectual authority of a text was directly proportional to its antiquity. This is the case of the Zohar, one of the most important kabbalistic works produced by Iberian Judaism, probably written by Moshe de Leon $\left(13^{\text {th }}\right.$ c.), but attributed to Simon bar Yochai (Scholem 1941: 153). However, relevant $20^{\text {th }}$ c. researchers on that field-such as Gershom Scholem 1987, and Moshe Idel 1988 - have shown that Kabbalah (in its current meaning) has its origins in Provence and Catalonia. 
Kabbalah was the result of an unsolvable tension between tradition and innovation. The target of the first kabbalists was the development of new exegetical methods of reading the sacred texts to discover the true nature of God, the absolute knowledge, which is hidden behind their lines. These theosophical trends led to theorization about some foundational concepts, like the divine ontology of the Sefirot or the Devekut (communion with God), the final goal of Kabbalah. The sources remained the same, but the approaches changed. Innovation, viewed as revelation, became a virtue. It can be traced from the more spiritual and introspective topics of Kabbalah and their poetical expression. As Jacob ben Sheshet stressed: "Everything that a man on the path of faith can devise anew in the Torah [that is, by studying the Torah] serves to propagate and glorify the Torah" (Scholem 1987: 380-81). Jewish Kabbalah accomplishes this role of origin, transmission and transformation of culture. The Kabbalah certainly depends on the economic and social context, but its internal structure has worked to educate and acculturate a wide range of different social groups, and it is flexible enough to allow its uninterrupted reinterpretation according to several different theoretical tendencies and historical events. Briefly: it has been institutionalized in many ways.

The myth, the narration, of Shevirat Ha-Kelim, for example, still plays an ontological role and has contributed to the regeneration of Jewish identity after the Holocaust. ${ }^{1}$ It means "the shattering of the vessels", and it is a foundational myth in Jewish cosmogony. For the Kabbalah, the vessels are the first receptacles of the Divine Light. The story has been narrated in many different ways, but all the versions contain the same basic elements: the universe is the result of a divine contraction (tsimtsum), and not the result of an expansion of matter (energy), as contemporary astrophysics conceives it. The creator contracted himself in order to produce the matter. He first held His breath, producing darkness, then light. He sent ten vessels (Sefirot) to bring the world into being. From the perspective of the creature, creation becomes Yesh me-Ayin (something from nothingness). From the divine perspective, creation becomes Ayin me-Yesh (nothingness from something).

The myth continues as follows. Incapable of constraining the Divine Light, the first seven vessels shattered, and the remaining three cracked. The pieces contained the essence of God and, after they have been shed across the world, they originated the resistance against the same God that had created them-because He cannot be contained in any form or manifestation. So, evil, disharmony, discord, has its origin in goodness too. Human beings find ourselves reflected on this imperfect mirror. God disappears to push us to find Him again in our souls. For all humans there is no other way to receive the infinity and to achieve knowledge. You have first to go down to the bottom to be able to ascend later. This entails pain. God created the world so that human beings — and especially the Jewish people — could rise up again and again. We are simultaneously a target for both devastation and miracle.

The myth is usually linked to the Lurian rabbinic Hebrew mysticism, coming from Rabi Isaac Luria Ashkenazi (Jerusalem 1534-Safed 1572). Some other narrations have been also associated with this myth, such as the one about the sacrificial death of the ten rabbis, condemned by Emperor Hadrian to get burnt into the rolls of the Torah. However, the myth of the creation and the

\footnotetext{
${ }^{1}$ See the artistic reflection on confronting the past, myths and disharmony contained in the works by Ingebor Bachmann and Anselm Kiefer.
} 
symbol of the light are much older. It has been one of the constants in sacred philosophy and poetry of the Early Middle Ages, especially flourishing in the Iberian Peninsula (Sefarad), as proved in the many works of one of the most interesting researchers of Sephardic Judaism, J.M. MillàsVallicrosa (1940).

Medieval Catalonia was a land of political dialogue, religious thought and feudal fights. The rise of Jewish mysticism coincided in space and time with the new-born Christian Scholasticism and apologetics. Some of the main representors of both sides produced and cohabited in Catalonia, such as Moshe ben Nahman [Nahmanides, Ramban, Bonastruch ça-Porta] (1194-1270), Ramon de Penyafort [Raymundus de Pennaforte] (1180-1275) or Ramon Martí [Raymundus Martini] ( 1230 -1284). It led to a strange relationship in which hate, mystics, rationalism, proselytism, and resilience were indissolubly interconnected. These exchanges and mutual influences spread along all the dimensions of daily life. It might be evident, for example, in the language: the use of vernacular ancient Catalan and Hebrew are entangled. El Cant dels Segadors (the Catalonian anthem) praising the Catalan revolt in 1640 could have its origins in a Jewish melody (Ein $K^{\prime}$ Eloheinu). Since the $12^{\text {th }}$ c., kabbalists from Provence, Girona and Barcelona such as Jehuda ben Yakar $\left(12^{\text {th }}-13^{\text {th }}\right.$ c.), Ișhaq Saggi [Isaac the Blind] $(1160-1235)$, Joseph ben Shalom haAshkenazi $\left(13^{\text {th }} 14^{\text {th }}\right.$ c.), and Shelomo ben Isaac Gerondi $\left(13^{\text {th }}\right.$ c.), elaborate upon mysticism as the only way to reach the true knowledge, in contrast with Maimonides' rationalism (Vajda 1963, 1977; Riera 1986b, 1987). ${ }^{2}$ They were intellectually related-Nahmanides was an advanced student of Azriel ben Menahem [Azriel of Gerona] (c.1160-c. 1238), and Azriel was an advanced student of Isaac the Blind. Jaume Riera (2014) has shown that many early medieval writers were known with a double name, in Catalan-Latin and Hebrew. ${ }^{3}$ He insisted on the non-Sephardic origin of Jews in Provence, Girona and Barcelona.

Moshe ben Nahman Gerondi (Bonastruch sa-Porta), leader of the Kabbalist School of Girona and rival of Pau Crestià in the Disputation of Barcelona (1263), describes the movement of the soul as follows:

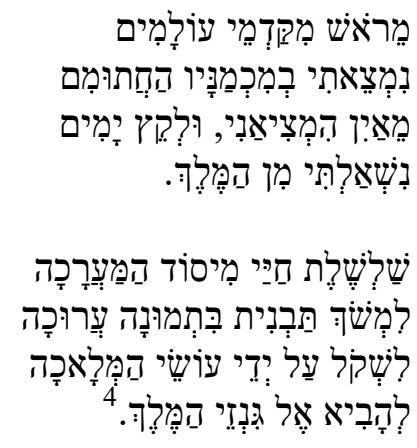

\footnotetext{
${ }^{2}$ Georges Vajda (1908-1981) kept a detailed account of the advances in this field with many reviews from 1954 to 1977 generally entitled "Recherches récentes sur l'ésotérisme juif". Jaume Riera i Sans (1941-1918) summarized the research on Catalonia and the Crown of Aragon from 1929 to 1984 in two bibliographic articles with the title "Estudis sobre els jueus Catalans".

${ }^{3}$ Riera (2014: 13) offers a succinct non exhaustive roster, in chronological order: Meixul·lam ben Xelomó de Piera (En Vides de Girona), Menahem ben Xelomó Meïrí (Vidal Salamó Mahir), Yedayà ben Abraham ha-Peniní (Bonet Abraham), Yossef Kaspí (Bonafós de l'Argentera), Moixè ben Yehoixua Narboní (Vidal Efrahim), Menahem ben Abraham (Bonafós Abraham), Yishaq ben Moixè ha-Leví (Profiat Duran), Yehoixua Abenvives ha-Lorqí (Astruc Lorquí), Zerahyà ha-Leví (Ferrer Saladí) i Azaryà ben Yossef ben Aba Mari(Bonafós Bonfill Astruc).

${ }^{4}$ Cfr. שירמן [Schirmann] (1954-1956, II : 322).
} 
From the beginning, before the world ever was, I was held on high with his hidden treasures.

He brought me forth from nothing and

in the end I will be withdrawn by the King.

My being flowed from the spheres' foundation, which endowed it with form in evident fashion. The craftsmen's hands weighed its creation, so I would be brought to the vaults of the King.

(Translated by Cole 2007: 234)

In these verses, Nahmanides conceives his existence and indeed every human existence, as a premeditated part of the divine plan of creation. The worldly existence of the soul within the human and temporal body is a journey from God to God. For Nahmanides, the Genesis does not describe a complete act of creation, but just the beginning of a continuous process of birth and regeneration (Caputo 2007: 63-64). In his exegesis of Jewish cosmogony ${ }^{5}$, there are just three things that were directly created by God from nothingness: the earth, the skies, and mankind (Ramban 2004, I: 23-25, 93-94). Thus, human kind emanates from the divine substance, from the foundation of the spheres, the sefirah ha-yesod (יסוד), one of the ten vessels. However, this soul, which was created in the spiritual image of God (Ramban 2004: 73-74) and which will be called back again by Him, is roaming across the sensitive world, surrounded by sin and lust (Millàs $i$ Vallicrosa 1940: 142). To achieve this return, the soul must deserve it. It must not be so highly corrupted as not to deserve to become again one with God. For that reason, there will be a judgement on the soul once it has left the material body and before allowing it to enter in the vaults of the King, the sphere of divinity. This is Kabbalah for Nahmanides: a way back to God.

\section{VIOLENCE AND CULTURAL BLEND}

According to Gershom Scholem, modern Jewish philosophy and historiography filtered the myth of Shevirath Ha-Kelim through the history of nineteenth and twentieth centuries. The Lurianic perspective of sixteenth and twentieth centuries was a reaction to the exodus of the late fifteenth centuries (Funkenstein 1993: 204-205). From the Girona School to after Luria Hassidism, the individual understanding to assume and reconstruct history would have been reached. Communion with God (Devekut) is internalized. Sholem established the thin nexus between the school of Girona in $13^{\text {th }} \mathrm{c}$. and modern hassidism based on the texts of this school, especially on those by Azriel of Gerona:

Hasidic devekut is no longer an extreme ideal, to be realized by some rare and sublime spirits at the end of the path. It is no longer the last run in the ladder of ascent, as in Kabbalism, but the first. Everything begins with man's decision to cleave to God. Devekut is a starting point and not the end. Everyone is able to realize it instantaneously. All he has to do is to take his monotheistic faith seriously. (Cfr. Sholem 1971: 208)

\footnotetext{
${ }^{5}$ For Nahmanides' hermeneutical methods and their relation with his comment on the Genesis, see. Wolfson 1989.
} 
Coping with disgrace becomes an essential attribute of Jewish identity, for it entails the acceptance of the breach of tradition and the risk of destruction. As stated by Gershon Greenberg, "Shevirat ha-kelim represents not only the breakdown in the nineteenth century of traditional structures in both philosophy and Jewish life, but also the possibility, in the absence of such structures, of pluralistic and dynamic responses to the cataclysms of the twentieth century" (Greenberg 1996: 111). In the interpretation recently made by artist Anselm Kiefer (2007), the shattering of the vessels is linked to the events of Kristallnacht (9-10 November 1938) and the prior bonfires of books in Austria and Germany. Shevirat Ha-Kelim inspired SternenFall, a sculpture work made of lead, glass and steel which results from the Jewish tradition of selfreconciliation and forgiveness in order to cope with memory of the extreme violence of the twentieth centuries. $^{6}$

We have already shown that this resumes a past and long story. There is a wide memory including both pain and joy, which allows resilience and internal resistance to adversity. There is both conflict and harmony between the individual and the community, which builds the necessary bridge between the soul and God. Iṣhaq ben Sheshet Perfet (1326-1408) from Barcelona, who was also rabbi of the aljamas of Saragossa and Valencia, wrote in his sacred lamentation:

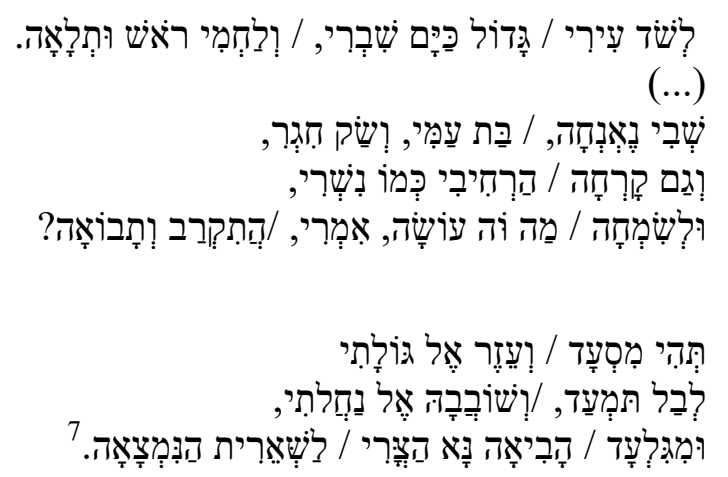

As deep as the sea is my pain

And I feed myself with weariness and sorrows.

Now my city is desolated.

Cry, daughter of my people,

And dress for mourning,

Pull your hair up

Until you become bald like a vulture.

Which is the benefit of happiness?

Maybe the day in which God will make a decision is coming?

Hold me, Lord,

And protect me in my exile,

Make my legacy not to totter nor tear.

\footnotetext{
${ }^{6}$ Kiefer, A. SternenFall/ Shevirath Ha-Kelim (Falling Stars/Destruction of the Vessels, 2007). MONA, Hobart.

${ }^{7}$ Cfr. שירמן [Schirmann] (1954-1956, II : 559-561).
} 
Make the balm of Gilead come

For whom still remain ${ }^{8}$.

Let's develop a bit more the "baldness of the vulture". Actually, this poem is the quinà (lamentation) that the rabbi Sheshet Perfet wrote after his flight to Alger, just after the anti-Jewish disorders of Valencia and Barcelona of July and August 1391 (Hershman 1943: 30-31). On July $9^{\text {th }}$ 1391, around two hundred and fifty Jews (out of an estimated population of 2,500 ${ }^{9}$ ) were murdered. Sheshet, then the leading rabbi of Valencia, converted to Christianity to save his life, taking the name of Jaume de Valencia and joining the Dominican Order. We are quoting at length the hypothesis of Jaume Riera about this issue, because it shows how the royal power had to proceed to restrain the riots ${ }^{10}$.

When prince Martí and his officers realized that the best way to calm down the popular riot in the city was to convince the Jews not to resist to baptism, and that the best argument for that was to convince the Rabbi first, they caught Issach Perfet,, and asked him to convert, trying to make him understand that this was the best way to stop the confrontation and to avoid the massacre of his co-religionists. Rabbi Issach Perfet declined the offer. Once all the available mechanisms to convince him to convert failed (bribes, threats, etc.), they made him one last offer: some paid witnesses would declare he committed an ignominious crime - such as having sexual relations with a Christian woman-, and the General Attorney would write the indictment according to which he would be condemned to die in a bonfire... unless he accepted to be publicly baptised. In front of such a horrible and unfair death, and for non-religious reasons, Rabbi Issach Perfet abandoned this attitude and embraced baptism, for which he was liberated and this parody of summary prosecution was dismissed. Once they had accomplished their objective, prince Martí and his officers spread the news about the baptism of the Rabbi - in which he was given the name of the cardinal and bishop of Valencia, Jaume of Aragon, who was living in Avignon by the time and was praised as exemplary. ${ }^{11}$

The legend tells that Isaac Perfet, while in prison, drew with coal a ship on the wall, and God made it land in Alger. As a matter of fact, he reached the city more than a year later, and approximately at that time he composed the quinà (Riera i Sans 1986: 48).

Jewish culture has had to learn how to get along with danger, disappointment and death. But there is something else: cultural blending. Moshe Remos, who was born in Majorca and was a doctor in Sicily, was falsely accused of poisoning and forced to accept conversion. He didn't do so. He was executed at the age of twenty-four in the central square of Palermo in 1430. The day before his execution, he wrote:

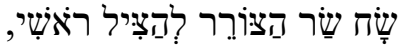

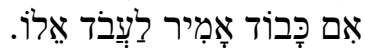

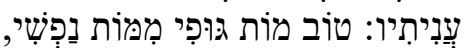

\footnotetext{
${ }^{8}$ Our own translation (MM).

${ }^{9}$ According to Gampel (2016: 24-26).

${ }^{10}$ This interpretation has been recently challenged and corrected by Roth (2011). According to him, it cannot be inferred from the documents that Sheshet converted or was even accused of sexual crimes. But Roth also confirms and stresses the strong measures set by the prince to protect the Jews and find and punish the murderers.

11 Riera i Sans (1986: 47) (our own translation, PC).
} 


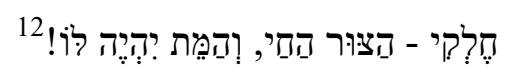

The tyrant's vizier offered to save me

if I would abandon my Lord for his;

but better to die in body than spirit

and give my portion to the God who lives.

(Translated by Cole 2007: 328)

There is sufferance, but also anger and pride in this reply. What we mean is that inner blended social cognition underlies narration, account and speech, and plays an important role in the creation and transmission of cultural identity. Hence, identity becomes hybrid and personal, and a result of transmission through contextual written, spoken, heard and visual natural languages. But identity is a bit more complex than just language, because its matrix cannot easily be parametrized. Cultural flows define individuals, but these are autonomous individuals that can decide by themselves how to use the linguistic materials that they have at hand. Experiences are fed by this blending process, and the result is not always foreseeable.

Dialogue and interaction - and also dispute, controversy and conflict - are essential to understand the tension between tradition and innovation that we addressed at the beginning of this article. Cultures originate and stay, survive or disappear in multiple ways, and can reawaken and develop new ethos and idiosyncrasies. And they can do so foregoing the circumscription of the space and the chronology of time. We can compare this with Christian apologetics, the counterpart of Kabbalah and Jewish culture.

\section{ROOTS OF THE INTELLECTUAL INCOMPATIBILITY}

We should start at the beginning, at the origins of Catalan anti-Judaism. But when did it begin? We can only rely on facts and ideas, though the inner gestation of people's convictions always remains unknown. Those blurred origins had probably to be sought in Saint Paul's Epistle to the Romans - "the most important political theology"13 — and in the eschatological seeds of Western political constructions, as Karl Löwith (1949) and Jacob Taubes (2009) suggested. Augustine of Hippo (1890: Book XI onwards) rationalized this eschatology in a symmetric and hierarchical correlation of worlds: if the Kingdom of Heaven represents justice and perfection, the earthly government ought to be its reflection. This notion was an immovable axiom for medieval political theology. The initial statement in Catalan legal compilations referred to those seeds: "En nom de la Sancta, e individual Trinitat, la qual lo món en son puny continent, als imperats impera, y mana, e als senyorejants senyoreja" ["In the name of the Holy and individual Trinity, which holds the world on its hand, and rules and commands over the ruled, and lords over the lords "] ${ }^{14}$. In this ideal Christian society, Jews must be respected and guided to the true faith with words and love, because they are living witnesses to the price that the infidel has to pay for his heresy: exile, poverty and marginalization (Augustine 1995: 180-183).

\footnotetext{
${ }^{12}$ Cfr. שירמן [Schirmann] (1954-1956, II : 646-647).

${ }_{13}$ Jacob Taubes (2013), in a letter to Carl Schmitt (18 September 1979).

${ }^{14}$ Constitutions y altres drets de Cathalunya (1973: 7, our own translation, MM).
} 
The patristic approach to Paul set a limit to physical violence but encouraged hate. In a society built upon eschatological bases, in the desire of judgement and salvation, evil forces are real and proactive. The infidel is by definition an embodiment of those forces, a threat both to earthly and spiritual Christendom. Ramon Martí noted: "Nullus autem inimicus Christianae fidei magis sit familiaris, magisque nobis ineuitabilis, quam Iudoeus" ["No enemy of the Christian faith is greater, more familiar or more inescapable to us than the Jew" $]^{15}$. Violence somehow contributed to accomplish the mystical role assigned to Jews as witnesses to the truth in Christ.

The lay legal development inspired by the Augustinian thesis attests to this fluctuating trend between tolerance and hate. The Visigoth Liber Iudicorum $\left(7^{\text {th }}\right.$ c.) contained perhaps the harshest rules ever enacted against Jews in Western Europe until the Laws of Nuremberg ${ }^{16}$. The principles of Ius Commune set by Justinian and Canon Law virtually excluded Jews from public and social life ${ }^{17}$. These rules were inherited by Catalan law and inspired posterior legislation, but they cannot explain the generalized outbreaks of violence of the $14^{\text {th }} \mathrm{c}$.. Catalan monarchs attempted to protect their Jewish subjects because they were a large source of incomes for the royal treasury.

Christian violence had deeper intellectual roots. They were progressively provided by scholastic theology throughout the $13^{\text {th }}$ c.. Aristotelian logic and dialectics, as well as the study of Hebrew sources, were placed at the service of apologetics. Reason was used to demonstrate the veracity of Christian faith; thereby Jews could not be considered erring passive witnesses anymore, but liars who persisted in their perfidy (Cohen 1983). In the recently published multidisciplinary work The Talmud in Dispute During the High Middle Ages (Fidora and Hasselhoff 2019), Alexander Fidora, Görge K. Hasselhoff and the rest of participating authors ${ }^{18}$ have proved that the discovery of the Talmudic corpus became a cornerstone in the history of Christian-Jewish relations. The theological depth of the Talmud and its commenters implied that the Jews were a serious theological depth. The anthological translations of Talmudic passages contained in De articulis litterarum Papae ${ }^{19}$ (1238) and the Extractiones de Talmud ${ }^{20}$ (1248) ushered the new apologetic approaches of the Church.

The compilation of the feudal Catalan law, the Usatges de Barcelona [Usatici Barchinonae], written between 1035 and 1076, and many times interpolated and republished until the $18^{\text {th }} \mathrm{c}$., contained many references to Jews, under the protection of the Crown. Usatges [Uses] 11, 51, 64, 75, 129, 164 and 171 refer directly to Jews (Gonzalvo i Bou 1996). Number 171, known as Hec est forma is unusually long. It was in fact added in 1241, and James I laid it down for the whole country. It described in detail the compulsory (and humiliating) oath that Jews had to perform before the Courts in lawsuits and litigation with Christians, who were exempt (Cfr. Muntané i San-

\footnotetext{
${ }^{15}$ Raymundi Martini Pugio fidei, 1651. Paris, 1651, 2. (Our own translation, MM)

${ }^{16}$ Liber iudicum popularis, 2003, Book XII.

17 Code of Justinian Book I, 9, in Corpus Iuris Civilis (Vol. II). Consilium Lateranense IV (1215), at http://www.internetsv.info/Lateranense4.html . Decretals of Gregory IX V, 6, at http://www.canonlaw.info/canonlaw IUSDECR.htm

${ }^{18}$ Ursula Ragacs, Piero Capelli, Ulisse Cecini, Óscar de la Cruz, Federico Dal Bo, Eulàlia Vernet, Enric Cortès, Wout van Bekkum and Moisses Orfali. The book has been produced within the framework of the ERC project The Latin Talmud and Its Influence on Christian-Jewish Polemic (LATTAL).

${ }^{19}$ Thirty-five accusations against the Talmud submitted by the convert Franciscan friar Nicholas Donin to Pope Gregory IX. A critical edition was prepared by Óscar de la Cruz and Ulisse Cecini in Fidora and Hasselhoff (2019: 59-100).

${ }^{20}$ A translation of 2,000 Talmudic passages by request of Pope Innocent IV. A critical edition of the text has also been published as part of the outputs of the LATTAL project (Cecini and de la Cruz 2018).
} 
tiveri 2014). Usatge n.164, on murder, equates Jews with criminals, adulterers, thieves, murderers, Muslims, heretics and the excommunicated. They were equally prevented from giving testimony in criminal cases against Christians, as contra omnes Christianos semper sint alieni.

However, we should not succumb to the temptation of looking for a single culprit in the shadows or falling in a comfortable Manichaeism. Attempting to attribute the entire responsibility of Late Medieval anti-Jewish violence to intellectual and legal subtleties would be a burlesque, and even absurd, simplification. Hate and appetite for violence can be rationalized in so many ways with philosophical elegance and incontestable logical arguments; but its most elementary foundations, the primal willingness to materialize this aversion in physical violence, do not require epistemologies or metaphysics.

The history of medieval violence against Jewry cannot be properly understood if one does not look at the total picture. Both Jews and their persecutors were not alien to the complex and changing economic, social and political dynamics of the thirteenth, fourteenth and fifteenth centuries. The embryo of violence in Catalonia was persistently molded by an unmanageable and sometimes unnoticeable set of factors until its final explosion in 1391. It cannot be a coincidence that the wave of anti-Jewish riots in Catalonia since 1348 overlapped with the increasing popular unrest that culminated in the general peasant uprisings of the second half of $15^{\text {th }} \mathrm{c}^{21}$. Apologetics and the missionizing zeal just contributed to chart a way that people were already prone to follow. We are not going to discuss the proper origins of violence here, but the foundations of its ideological coverage.

The disputation of Barcelona in 1263 was the first manifestation of the new missionizing strategies in Catalonia. For four days Pau Crestià [Pablo Christiani] (?-c.1269) a convert who had joined the Dominican order, and the leading Jewish scholar Moshe ben Nahman discussed exegesis and messianism. This disputation was not a mere private discussion between two men of faith. It had been carefully organized, aiming to demonstrate the falsities and incoherencies of Jewish doctrines and interpretations on messianism. In other words, the target was to prove rationally the veracity of Christianity through Jewish sources (Caputo 2007: 91). The list of attendees to the Disputation of Barcelona gave evidence as to its significance: King James I the Conqueror presided over the event in the royal palace and Ramon de Penyafort, one of the main leaders and ideologists of the Dominican order, guided the discussion (Nahmanide 1984: 26-27).

Nahmanides probably realized how delicate his situation was, as well as the necessity for diplomacy. Although the king guaranteed his right to speak freely, his integrity and the security of the aljamas depended on his skills to deal carefully with his exposition. King James I as well as his son Peter the Great, regularly appointed Jewish officials and often relied on their knowledge and advice. In addition, he maintained a relative political line of tolerance toward Judaism (Baer 2001, I: 138-147). However, he was a pious Christian King; thus, he was biased. He had to be. These circumstances converted the debate into a farce. It was impossible for Nahmanides to expose their arguments freely in such a threatening political ambiance. According to the Hebrew report of the debate, on the last day, the Jews themselves and some Christian friars begged

\footnotetext{
${ }^{21}$ The relationship between the Black Death and the fifteenth-century peasant revolts in Catalonia has been widely studied and accepted since the beginnings of the $20^{\text {th }}$ c.. For a bibliographical survey, see Salrach i Marés (1989).
} 
Nahmanides to leave the debate, requesting him to prioritize his personal security and the security of the community (Nahmanide 1984: 51-52). James I did not allow such a course of action. The next day Nahmanides was forced to surrender and to accept the king's verdict which declared Pau as the winner of the debate. In intellectual terms, the disputation ended up in an unsolvable stalemate.

The consequences that followed the dispute were catastrophic for Jewish communities (Chazan 1992). The victory legitimatized the Dominicans' fight against the enemies of the True Faith. Several royal edicts and papal bulls were promulgated for that purpose. Some of the repressive measures included the censoring of Jewish books, mandatory Christian sermons and prayers in the synagogues, and the creation of a commission (composed of Raymond Martí, Raymond of Penyafort and Pau Crestià, among many others) in charge of enforcing these decrees. In fact, one of the first tasks conducted by this commission was the legal prosecution of Nahmanides for his report of the disputation. However, James I denied all the accusations, alleging that Nahmanides acted under royal consent and protection ${ }^{22}$. The king maintained his decision despite the protests of the Pope, who demanded the execution by dismemberment of the Ramban ${ }^{23}$. Regarding this type of experience, it does not come as a surprise that Nahmanides considered Rome and the Church the embodiment of the fourth beast of the prophecy of Daniel (Daniel 7:7), the one that will be defeated by the arrival of the Messiah. ${ }^{24}$

Perhaps the most remarkable lesson we should learn from the Dispute of Barcelona is the virtual impossibility of dialogue. Obviously, the social and political preponderance of Christian authorities in front of the weak and delicate situation of Judaism hindered any dialogue in an equality of conditions. We now refer to the intellectual background of the dispute, to the differences between the theological methods of both religions. In the $13^{\text {th }}$ c., Jewish and Christian theology in West Europe were opposites poles within the traditional philosophical spectrum. While Judaism was immersed in a mystical renaissance close to esotericism (Kabbalah and the rejection of Maimonides' works give evidence to this trend), Christianity was rediscovering Aristotle and his logic and rationalism.

The debate between Nahmanides and Crestià evidenced these philosophical discrepancies. Pau Crestià based his statement on the literacy of Hebrew sources. His analysis of biblical times and events was rational, almost historiographical. For his part, Nahmanides' kabbalistic understanding of the Hebrew sources was rather allegorical. He kept the platonic dualistic division between the material world and the spiritual world. According to his exegesis both worlds coexist in a sort of parallelism (Wolfson 1989: 111-112) and both converge in the Torah: the divine substance is hidden within the sacred text. Words can be mathematically decomposed and composed again in order to reveal mystic secrets about God and His nature. In the Torah nothing is casual, nothing can be literally read, but every word, every narration or date has an esoteric and symbolical value (Ramban [Nahmanides] 2004: 11-14). Biblical time is a fluctuating line that links both worlds. The time in the Torah is also metaphorical, it reflects deeper mystical conceptions. The

\footnotetext{
22 "Documentos", N ${ }^{\circ}$ CXXI in Summa Iuris, 1945, p. 157-158. The letter was written the 12 of April of 1265.

${ }^{23}$ Nahmanide (1984: 95). The letter was written the 15 of July of 1267.

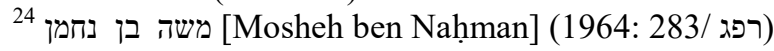


interpretation of time by Crestià, which was one of the main pillars of the discussion, had nothing to do with Nahmanides' conception (Caputo 2007: 59ff).

Intellectual incompatibilities, however, were not limited to metaphysics. They were much deeper. Discrepancies in mathematics and on the processes of logical constructions largely hindered mutual understanding. Mathematics relies upon an agreed set of axioms and inference rules for deriving new knowledge from the axioms. For thirteenth-century Christian theology, the religious dogma accomplished this immovable axiomatic function (for example, the Sun goes around the Earth and the world cannot be eternal), and those who disagreed with this axiom were punished.

On the other hand, Domènech et al. (2018), delving on the neoplatonic principle of the identity of the multiple (coincidentia oppositorum) and the Kabbalah, note that Paraconsistent logic admits contradiction. In paraconsistent logic the truth values are roots of the equation $p^{2}-p+1=$ 0 . This equation has no real roots but admits complex roots. This is the result which leads us to develop a multivalued logic of complex truth values. They note that sum of truth values is isomorphic to the Cartesian plane $\mathrm{R} \times \mathrm{R}$. The general theory of complex numbers requires an understanding of Cartesian coordinates. And Descartes lived in the $17^{\text {th }} \mathrm{c}$. - we will adopt as valuations the norms of vectors. So whilst Domènech establishes a theory of truth-value evaluation for paraconsistent logics with the goal of using them in analysing ideological, mythical, religious and mystic belief systems, $13^{\text {th }}$ c. Catalans did not have access to such logics. However, the notions were there. Nahmanides (and his mentor, Azriel of Gerona) argued that truth was not an absolute concept. These notions are conceptual and have formalisms for understanding rationality. Therefore, both participants and both religions were destined to not comprehend each other.

The intellectual confrontation was not, nevertheless, binary. It was not as simple as a confrontation between Jews and Christians. The situation was more complex since medieval Jewry was not a homogeneous group with central authorities and well-defined hierarchies. Unlike the Catholic Church, whose dogma was unitary and politically institutionalized, Judaism lacked - and still lacks - those elements. The religion set in the Mount Sinai and enlarged by the prophets was a state religion. The Israelites were not only members of a religious community, but the subjects of a Jewish political structure erected over four pillars: a kingdom, a king, a priestly caste, and a temple as a central political, social and religious symbol of the Jewish state. All elements ended abruptly with the destruction of the Second Temple (70 c.e.). These traumatic events led to the dispersion of the people of Israel across three continents and to the beginning of a process of cultural, social, exegetical and political decentralization.

Decentralization was always present in all aspects of diasporic Jewish history. Each community became a sort of small state within another state (Baron 1942, I: 208; Elazar 1977: 19), in which its members were to communal ruling institutions "as all Israel to the High Court and to the King”, according to the Jewish doctrine in Catalonia ${ }^{25}$. The relative isolation of these population groups contributed to the individual development of communal self-government models. Throughout the Middle Ages, some influential Jewish scholars succeeded in achieving a certain degree of homogeneity among the communities within delimited geographical and cultural areas.

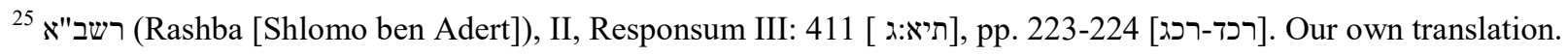


This is the case of the Geonic period ( $7^{\text {th }}$ to $11^{\text {th }}$ c.), when the scholars of the BabylonianIraqi - academies enjoyed an almost undisputed authority among the Jewry of the Islamic world; the Tosafists (eleventh to fourteenth centuries) in Central Europe; or some renowned scholars in the Iberian Peninsula, such as Meir Abulafia (1170-1244), Asher ben Jehiel (1250-1327), Shlomo ben Adret (1235-1310), Sheshet Perfet (1326-1408) and Isaac Abravanel (1437-1508).

Lack of homogeneity was a predominant feature. Political, legal and intellectual formulations were as diverse as the social, political, cultural and economic contexts of the communities (Freeman 1981). Context was an essential generative element for the definition and development of legal, political and intellectual systems. The specific economic necessities and structural particularities of each neighborhood required local solutions and precluded unitary responses. Also the politics and intellectual trends of the host kingdom had great impact on communal political life and organization.

The gestation of Kabbalah and the response to Christian apologetic onslaughts in Catalonia and Provence clearly attest to this phenomenon. The first schools of the Kabbalah in the late $12^{\text {th }}$ c. arose at the same time that Jewish rationalistic philosophy reached its peak. Cultural blending played a major role in those apparent paradoxical situations. Maimonides was born in the Andalusian city of Cordoba (1138) in a moment of great fascination for the works of Aristotle, the first master. In this period, Muslim thinkers such as ibn Tufayl (1105-1185) and ibn Rušd (11261198) developed philosophical systems based on Aristotelian orthodoxy. Maimonides' rationalism was, to some extent, a product of his times. In Catalonia and Provence, Jewish scholars were formulating their first mystic-philosophical systems relying on Neo-Platonism (Scholem 1987: 403; Dan 1985: 59).

The Maimonidean controversy (c.a. 1230-1235, and then almost to 1310) indicated the level of clashes between Jewish intellectual trends. The confrontation involved almost all the communities of Germany, France and the Iberian Peninsula. It opened a breach not only among communities, but also within the communities. The community of Girona in Catalonia is a clear example. While some of its members, such as Jonah Gerondi (1200-1263), were fierce critics of Maimonides, some others - especially in the case of Nahmanides - attempted to keep pacifying postures for the sake of unity (Twersky 1983; Scholem 1987: 403-404; Dan 1985: 42). In Barcelona, the virulence of the dispute led Shlomo ben Adret to issue a ban against the study of philosophy for minors under 25 years $^{26}$.

To this example of confrontation and dissension, we could add many others: the schism between Karaite and Rabbinic Jews (ca. $7^{\text {th }}$ c.); the messianic heresy of Abraham Abulafia (12401291), his confrontation with Shlomo ben Adret, and his hypothetical-though unlikelyinfluences on Franciscan spirituality ${ }^{27}$; the posterior messianic pretensions of Shabbatai Zvi in 1665, perhaps the largest messianic outbreak since the rise of Christianity (Sysyn 1992: 141); the aversions between Maskilim and Hasidim since the $18^{\text {th }}$ c., etc. The list is virtually unmanageable.

\footnotetext{
${ }^{26}$ רשב" (Rashba [Shlomo ben Adert]), I, responsum I: 415 [תטו:א], pp. 200-201 [רא-ר].

${ }^{27}$ On that issue, we should remark some works by Carreras i Artau (1949), Clifford R. Backman (1990, 2000) and Hames (2007).
} 
Decentralization and inner conflicts have always conditioned the social and intellectual interaction of the Jewish communities with their coreligionists and their environment. Within the scope of medieval Catalonia and religious violence and dialogue, it implied that there was little agreement amongst prominent Jewish scholars about Kabbalah and messianism. There was no way that they could provide a united front to Catholic theologians, nor to reach an agreement with the said theologians. Nor was there any agreed mechanism for how to determine truth or common ground on the nature of God.

Social and interfaith violence is an essential feature of Jewish identity (Abulafia 2001). Its traces have been perused in Western medieval tradition by twentieth century historiography (Moore 1921). The Holocaust stirred consciences and fostered scholarship far beyond academics. However, discrimination towards Jews, understood as violence and official hostility (Funkenstein 1993: 201-202), was not always an inseparable part of Christian-Jewish relations during the Middle Ages, but a phenomenon that arose after the year 1000. Jeremy Cohen (1984), Robert Chazan (1989, 1992), Anna Sapir Abulafia (1998), David Nirenberg (2015), among many others, have been consistently writing on the role of the Catholic orders - mainly the Dominican and the Franciscan orders - in the increasing intolerance in thirteenth and fourteenth centuries Europe. The Hebrew tradition in South Europe, the disputation of Barcelona and the fate of Hebrew sacred poetry are well-trodden paths. Why the Catholic dogma moved away from the Augustinian interpretation to embrace the Aquinas' views has been a recurrent question, related to the increasing power of the Church, the building of early medieval monarchies, and the homogenization of Christians as political subjects. Besides, the Kabbalah, the so-called Latin Cabala, political theology, and messianism beyond Hebrew sources have gained political philosophers' attention, and raised many controversies stemming from the seminal works of Gershom Sholem, Hannah Arendt, Leo Strauss and Carl Schmitt. The renaissance of Protestant, Catholic and Jewish theology in the interwar period was not alien to this kind of discussions.

\section{THE CHRISTIAN CANNON AND THE CATALAN MATRIX}

There is a new turn in historiography that profiles and adds complexity to the interpretations already in place. It focuses on pictures, images, technologies, situated local knowledge, life stories, and everyday life and practices (Brentjes and Fidora 2014). The approach that is often mentioned as a general Christian cannon based on documentary, epigraphic, textual, and translation studies is being completed with keen attention to the inner dynamic of interrelations, perceptions, and intellectual specific references as collective facts. There are ongoing critical editions of classical works - e.g. of Marti's Pugio Fidei and Llull's complete works - that can shed light on the epistemic and ontological dimensions of these works, their authors, their social impact, and the political and ideological landscape to which they contributed. The study of translations from natural languages (Greek, Hebrew, Arabic, Aramaic, Latin) needs to be more precise (Szpiech 2011 and 2014).

There is an emerging specific legal Catalan tradition on dialogue and violence that clarifies the legal and political innovations. Following the conquest of Valence, Murcia, Majorca, Sicily and Sardinia, these theologians and philosophers created this tradition. It is both partially coincident with the canon of the Catholic Church and equally non-compliant with it because it is 
grounded on a plurality of epistemic and practical reasons. There is no absolute power, nor absolute right to exercise violence, but there is a space for violence when fundamental values and beliefs are violated (see Fig. 1 below). We think that this early legal mold of the Catalan public law of the Crown of Aragon, based on covenants, pacts and principles-pactisme, pact-driven models - which was also used to plot commercial and international relations-e.g. Llibre del Consolat de Mar (1320) - furnished the stencil or pattern for the policy that was used to foster and eventually force the conversion of Jews and Muslims to Christianity.

Considering the inception of this legal pattern, the vertical axis is certainly the physical rule over the population held by the Prince, legitimated by the Decretals of Gregory IX, ran by the Inquisition under the Dominican order, and developed by the revival of Roman Law taught at the University of Bologna. The second horizontal axis is sustained by dialogue and reason. This kind of reasoning could eventually lead to the innovative way represented by the formal semantic graph and combinatorial techniques figured out by Ramon Llull's Ars of logic. In this latter sense, dialogue is not conceived as authority, but as formal reasoning. This extends and deepens the function of talking and reasoning (giving reasons) - in Catalan enrahonar - against the rule of using authorities to dispute: Disputar per autoritats no ha repòs, as advanced by Llull. Disputing on the grounds of authority never finishes (Cfr. Bonner 1990: 383). It is worth noticing that Llull's conception makes the semantics of theological attributes compatible with calculus, in the same way as the Kabbalah harmonised theological content and mystical form in a graded scale of knowledge. His probabilistic calculus had an impact on Leibniz ${ }^{28}$ and anticipated some of the graph-driven contemporary Artificial Intelligence solutions (Sierra 2011). We will come back to this issue later.

In the following centuries, the Catalan conception of law contended that the Prince had the summa potestas as the head of the mystical body constituted by the General of Catalonia within constitutional boundaries, but not plenitudo potestatis (Palos 1995; on the construction of Catalan Public Law, see Ferro 1987). This tendency to covenants and agreements in Catalonia was not a natural trend, but the result of a specific longstanding situation in which no group - noblemen, royalty, church or peasants - could prevail over the others, and this particular balance contributed to shape the institutional mold (Casanovas 2019) through the notion of jurisdiction (Montagut 1989). The recent discovery of the first official general compilation of Catalan public laws in the fifteenth century has confirmed this interpretation (Ripoll Sastre 2018).

According to this tradition, political power entails agreements, negotiations, balanced judgments, and civil institutions, as represented by the painter Lluis Dalmau in the Mare de Déu dels Consellers (Madonna of Council's Members, 1476), a realistic portrait of the Council's members. Athens, Jerusalem and Constantinople are similarly represented in the painting: The Council de Barcelona is kept equidistant from disputes and conflicts, ruled and inspired by the grace of the Holy Mother and Son. This civil projection of the mystical body of Christ helped to design the legitimation for the Catalan doctrine of legal pactism. "In Cathalonia rex solus non condit leges, sed rex cum populo" ["In Catalonia, the king alone does not enact any laws, but with the people alike" (Our own translation)], according to the public law tradition of Catalan jurists such as Joan

\footnotetext{
${ }^{28}$ See "Calculemus... " Leibniz 1682,; A VI 4 443; DA 216-217. In his manuscripts, The German philosopher also reflected on the immediate intuitive knowledge on God elucidated by the Kabbalah. See Foucher de Careil (1861: 5).
} 
de Socarrats (c.1426-1483-84) and Joan-Pere Fontanella (1576-1649) (Maspons i Anglasell 1932).

Yet, in the thirteenth-century Catalonia, pact does not appear under this mature legal form to balance social groups and conflicts. God is nested in the human mind, and the unknown remains under His sovereignty and the uncertainty ensued from the seeking of the truth. As Anthony Bonner notices, framing the dialogue on faith and worship is a strategy that relinquishes the sphere of reason to the adversary, but the final purpose of conversion is not forgotten (nor forbidden) (Bonner 1989). We could depict the argument schemes that lie behind these goals. According to the work by Douglas Walton and Chris Reed, argument or argumentation schemes are the forms of argument (structures of inference) that enable one to identify and evaluate common types of argumentation in everyday discourse (Reed and Walton 2001). Shaping the molds of being, reasoning and feeling for the Christendom was precisely one of the objectives of the Gregorian reform when the pope commissioned in 1230 the harmonization of Canon law to his chaplain and confessor, the Catalan Dominican Friar Ramon de Penyafort. He carried it out in four years, establishing the revealed faith and the pope' authority as the basic pillar of his Compilation (Decretales Gregorii $I X$ ). From this perspective, dialogue cannot be symmetric, and any theological argument carries on a pragmatic force as an adversarial speech act:

[1] I know that you believe that I am wrong I know that I am right

I am right

Or directly:

[2] I know that I am right

I am right

You are wrong

This could be deemed as belonging to a more general scheme, as drawn by Douglas Walton (1996: 62; also Reed and Walton 2001: 3), called the Argument from Position to Know with the following structure:

[3] Major Premise: Source $a$ is in a position to know about things in a certain subject domain

$S$ containing proposition $A$.

Minor Premise: $a$ asserts that $A$ (in Domain $S$ ) is true (false).

Conclusion: $A$ is true (false)

The Appeal to expert opinion argument, is a subtype of the first one, a fallible form of argument that carries probative weight. However, in this case, we think it is intertwined with an ad baculum argument, because of the implicit assumptions and entailed consequences of the conclusions. i.e. $A$ is deemed naturally true, and $a$ is in a position of imposing it by other means. Walton has pointed out that this implicit appeal to force—ad baculum arguments-requires three levels of analysis to conclude that they are fallacious: (1) an inferential level, (2) a speech act level, where conditions for specific types of speech acts are defined and applied, and (3) a dialectical level where the first two levels are linked together and fitted into formal dialogue structures (Walton 2014). The latter layer matters: pretending to advise while making a thread is a fallacy. 
Likewise, pretending to be fair in a dialogue while making a thread invalidates the dialogue itself. Fear and threat arguments share the same structure (Walton 2013).

We can add that in our view (1) and (2) operate in fact as counter-performatives: the mere $u t$ terance of any kind of argument against the conclusion invalidates the argument and the force of the argument, as the framework is asymmetric and does not guarantee the equal value and balance of both positions. Moreover, they are personal arguments, self-reflective arguments in the first person. This pragmatic paradox cannot be resolved by logical means, as well as the violence it contains and triggers. At the dialectical level, the type of speech acts and discourse selected in medieval disputes was not a common inquiry or an intellectual controversy. It was the first act of an inquisitorial play, and the Jews were very aware of it. They understood that the essential truth was supposed to belong only to one political community, i.e. to res publica christiana, as opposed to Jews, Muslims and heretic movements.

Jewish communities were the only ones that were allowed to live inside the Christian world, co-existing with Christians. As already stated in the past section, the theological justification goes back to Paul of Tarsus and the theological Augustinian justification based on the interpretation of Psalm 59.12 in his Tractatus adversus Judaeos:

Do you not rather belong to His enemies referred to in the psalm; 'My God shall let me see over my enemies: slay them not, lest at any time they forget your law. Scatter them by the power'? That is the reason why, not unmindful of the Law of God, but bearing that same Law about for a covenant to the Gentiles and a reproach to yourselves, you unknowingly are ministering the Law to a people that has been called from the rising to the setting of the sun. $^{29}$

Jews are witnesses, guardians of the Christian faith. The role of Scholastics and specifically Dominicans - the Black friars - in the evolution of this perspective between the 12th and 15th centuries has been extensively explored by contemporary historiography. Regarding Mediaeval polemical literature and disputations, Ora Limor has aligned the typology proposed by Amos Funkestein in 1968 with the one drawn one generation later by Jeremy Cohen (Limor 2010). The former identified four basic patterns: (i) the older pattern - a stereotypical repetition of biblical arguments; (ii) rationalistic polemics - demonstration of the philosophical superiority of the Christian dogma; (iii) the attack against the Talmud and the whole corpus of post-biblical literature; (iv) the attack from the inside, using the Talmud and post-biblical literature to demonstrate the veracity of Christian theological positions. Cohen proposes a functional typology and, as observed by Limor, shifts from the twelfth to the thirteenth century attributing the change to the polemical and missionary activity of the new mendicant orders (Cohen 1992).

Ramon Martí stated in his work Pugio Fidei (1278) that "there is no more familiar an unavoidable enemy for Christian Faith than the Jews" 30 , the dagger should be used to finish off "their impiety and shameless perfidy" (“impietatem atque perfidiam jugulandam") (Bonner 1989: 177).

29 Augustin of Hippo (1955: 387-417). Accessible at Roger Pearse's blog: $\underline{\text { https://www.roger- }}$ pearse.com/weblog/2015/06/11/augustines-treatise-against-the-jews/

${ }^{30}$ See footnote 15 . 
Jews are intentionally deceiving themselves. Hence, should they be accepted as members of the political community? Only if they convert.

[4] You know the truth

You know that you know the truth

You are intentionally lying

Assigning intentions to the adversary and reifying them is entering into a meta-pragmatic discourse that is beyond any rational possibility of dialogue. This lies at the core of the apologetic Christian canon. As asserted by Ryan Szpiech on Martí's use of Hebrew and Arabic languages, "he puts the text itself in display as a proof in service of his Christian polemic argument" (Szpiech 2016: 187). Hebrew sources are not only treated as authorized sources, but as imagined enemies.

In his translation to Latin into Hebrew characters and his transliteration of Arabic text into Hebrew characters, he does not only proffer the imagined knowledge of his polemic enemy. By giving these non-Jewish authorities a Hebrew garb, a form that is implicitly nonChristian but still comprehensible, he also aims to approximate the imagined perspective of the imagined Jewish enemy by simulating the authority of an 'original' (in this case nonLatin) text. (Szpiech 2016: 187).

The dynamic scalation from respect to enmity can be captured by the following matrix:

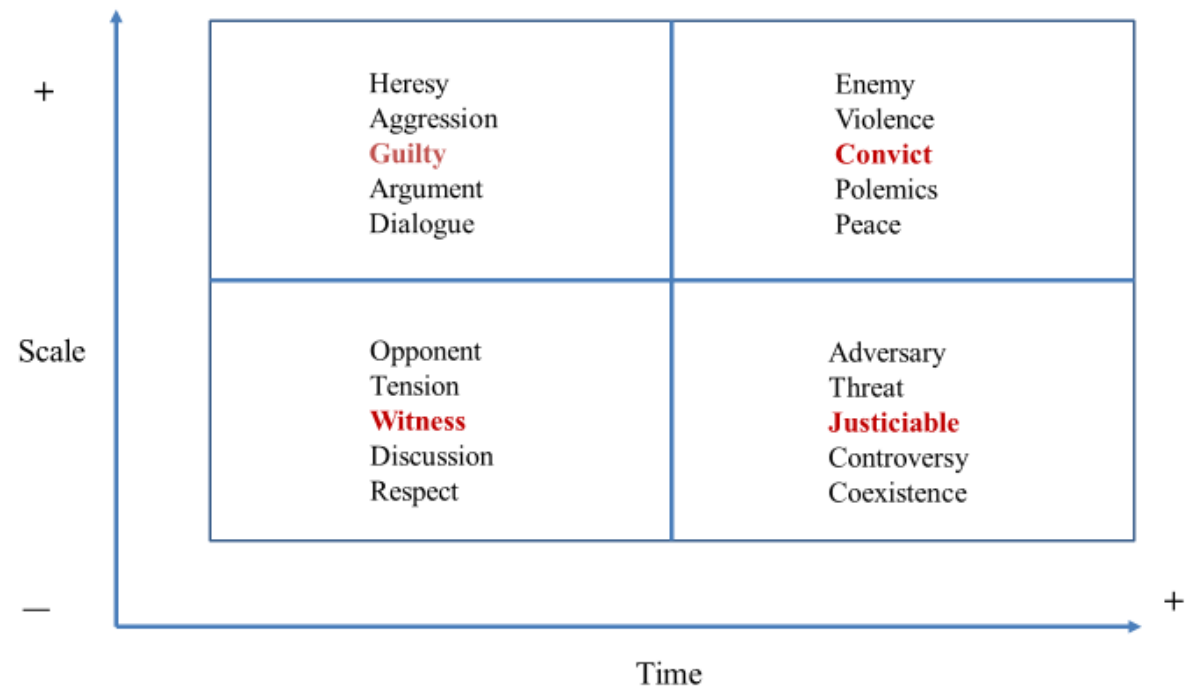

Fig. 1. Catalan matrix of dialogue and conflict

Fig. 1 plots the different outcomes along the two axes of time and the scalation of violence. It starts with the four quadrants of respect, dialogue, coexistence and peace, at the bottom. These properties figured out in the interaction of working social forces (the so-called braços) and fleshed out and constructed while scholastic philosophy was developing, were soon reserved for the Christian society. The initial purported dialogue with internal minorities (Jews and Muslims) turned them quickly into opponents, adversaries, heretics and eventually enemies. The matrix 
draws a conceptual idealization. This process occurred differently in time and space all along the Catalan territories and it is not exclusive to Catalonia. Other European and Mediterranean countries experienced a similar trend. However, because of the features of their internal conflicts and balances, Catalans friars could elaborate and think within this mindset in a more complete way than under other mediaeval monarchies, and the balance of dialogue, negotiations and concessions over rights and duties framed Catalan law and shaped the public space against the insideout movement of exclusion that was increasingly applied to those who resisted conversion. The stereotype advanced during the thirteenth and fourteenth centuries, and entered into an everyday moral scheme, setting the context of what Gigerenger has been termed fast and frugal heuristics for the average Christian use of moral common sense: ever since, up to the end of the $15^{\text {th }}$ century, the Jews were increasingly be considered liars, guilty, heretics and enemies, by default (Gigerenzer, II: 2008).

Unconverted Jews were also targeted by the Inquisition (Tartakoff 2012). Yet, the most relevant anti-Jewish riots in Catalonia and the Kingdom of Aragon in the fourteenth century were not exclusively addressed against Jews. Rich Christian patricians were also targeted, and we have already mentioned rulers' efforts to quell the riots and punish the culprits, although their efforts often were fruitless - for example, after the Black Death, King Peter the Ceremonious (1319-1387) had to absolve the greatest part of the culprits due to the material impossibility of trying them $\mathrm{all}^{31}$. Also, the bishops and other high territorial ecclesiastical authorities played an important role in the attempts to stop popular anti-Jewish uprisings. Violence had social origins. But the question about the hatred remains. David Nirenberg links it to the comprehension that both communities had of themselves, i.e. to the messianic identity of an accomplished future (Nirenberg 2007). Identification and segregation, including family and sexual relations (especially between Christians, those Jews who converted to Christianity, and Jews) constituted a problem during the $14^{\text {th }}$ c. and $15^{\text {th }}$ c. until the definitive expulsion of Jews in Spain 1492. Nirenberg also warns against the use of dichotomies such as tolerance vs. intolerance or construction vs. destruction of social bonds. It was a bit more complex than that, as violence could be considered as a component, a systemic aspect of the coexistence of majority and minorities in mediaeval Spain. Our matrix is an idealized abstract way of ordering the "punctuated" (Nirenberg 2002) or "pluralistic equilibrium" (Nirenberg 2015) of the dynamics of conflict and coexistence between Christians, Muslims and Jews in Catalonia. It cannot be interpreted in a linear temporal way.

There are two other relevant aspects to be considered. First, the asymmetry between Christianized Muslims and Jews. The former were mainly peasants, often enslaved, subjected to the jurisdiction of feudal lords (barons). The second group, the Jews, lived in towns, and showed a different degree of organization, literacy and culture, reflected in their bonds to the King's administration. Violence against peasants was a constant from the $11^{\text {th }}$ to the $15^{\text {th }}$ centuries and was legal, reflected into the so-called mals usos, ius maletractandi against the serfs, e.g. intestia, cugucia, eixorquia, arsia.

\footnotetext{
${ }^{31}$ Arxiu de la Corona d'Aragó [Archive of the Crown of Aragon, henceforth $A C A$ ], reg. 1321, f. 116r-v.
} 


\section{THE CATALAN MATRIX: DISCUSSION}

Let's describe how this conceptual scalation could take place after the failure of Crusades in the $12^{\text {th }} \mathrm{c}$. and the increasing intolerance against heresies in the first half of $13^{\text {th }} \mathrm{c}$. First Jews and Christian heretic movements were set apart. Jews had an old religion which had to be respected. In his casuistic compilation, Ramon de Penyafort chose not to address this issue into a sole section, but he distributed prohibitions and allowances regarding their relationships with Christians along the five books of the Decretales Gregorii (1234) (Watt 1992). He summarized them in Book I, Title $4^{\text {th }}$, of his Summa de casibus poenitentiae (1224-26) entitled De Iudeis, Sarracinis et eorum servis [On Jews, Saracens and their serfs]. He defended eloquently their right not to be converted against their will — the classical Augustinian view-but adding the Scholastic perspective on reason that the Aquinas would develop a little later:

As Gregory says, both Jews and Saracens must be called to the Christian faith with arguments, reasons and flattery, and they must never be compelled to do so, because coerced services do not please God (SdCP, I, 4,2). ${ }^{32}$

This general advice was enacted at the expense of a full apartheid at the social level. The III Lateran Council had prescribed in 1179 separate neighbourhoods. The IV Lateran Council had imposed the wearing of a batch on clothes. Thus, at the community level - in Catalonia: calls (neighbourhood), qehillot (political communities), aljamas (royal division of Jewish neighbourhoods) and taqqanot (ordinances) - Jews should be respected and integrated. However, by the same token, individual Jews should be segregated and could not interfere with Christians in their regular social life in any sphere (acquaintances; family; religious liturgy; public appearances; public honours, roles and charges, etc.). The only two tolerated exceptions were (i) the market; (ii) the political dependence on the monarchy, as subjects or serfs of the King.

Moneylending and usury were a common topic since the early Church. The positions against avarice and greed held by Basil of Caesarea, Gregory of Nyssa, and most notably John Chrysostom were well-known. For the early Church authors any interest was to be condemned (Llewellyn 2004). Scholastic theology was more flexible. How was the question of Jewish lending addressed in the Middle Ages?

Economic practices and the creation of business communities led to new conditions that challenged the general prohibition, and Jews were positioned to bridge them as the Old Testament prohibits interest among the Jewish people but allows it with foreigners (Deuteronomy 23.19-20). One may think that kings benefited from such a situation. However, Stowe contends that the formation of mediaeval $13^{\text {th }}$ c. monarchies in France and England around the concepts of patria, crown and kingdom brought the kings to "allow matters of a purely spiritual nature to blunt their good economic sense". They would set out to suppress Jewish lending in all its manifestations while "the popes explicitly and purposefully condoned and promoted the practice of Jews who lent at a controlled rate of interest" (Stow 1981). As already mentioned above, the Usatges of

\footnotetext{
32 “Debet autem, sicut ait Gregorius tam Judei quam Sarraceni auctoritatibus, rationibus et blandimentis potius, quam asperitatibus ad fidem Christianam de novo suscipienda provocari; non autem compelli; quia coactia servitia non placent Deo dist qui sincera". Summa Sti Raymundi di Penniafort, Barcinonensis, Ord. Praedeicator, de Poenitentia et Matrimonio, cum Glossis Ioannis de Friburgo. Roma, Ioannis Tallini (1703: 32-33).
} 
Barcelona prevented a balanced treatment of Jews and Christians in the frequent lawsuits that followed money lending, as Jews were deemed to be naturally prone to deceive.

Ramon de Penyafort was one of the most influential legal scholars of his time, confessor of Gregory IX, Master of the Dominican order, special advisor of James the Conqueror, king of Aragon, and teacher and friend of Thomas of Aquinas. He articulated the idea that Jews, as outsiders, could not be under ecclesiastical jurisdiction directly but indirectly, i.e. by way of pressure on Christians - i.e. on rulers who were held to enforcing ecclesiastical rulings and on Christians, who could be excommunicated for wrongful conduct (Watt 1992). The Church only could bring action against non-Christian in a scarce number of cases. The production of inquisitorial manuals attests the evolution of the Ecclesiastical jurisdiction over the Jews. The fist manual, written in 1249 by the Dominican friars Bernard of Caux and John of St. Peter in the midst of the antiCathar fervor, did not even mention the Jews ${ }^{33}$. In 1267, four years after the disputation of Barcelona, Clement IV issued the bull Turbato corde, which entitled Dominican and Franciscan friars to prosecute Jewish proselytes and blasphemers. Bernard Gui's Practica inquisitionis heretice pravitatis (1331), one of the most important guidebooks for inquisitors, included a number of sections deascribing how to proceed against Talmudic falsities, false converts, Jewish preachers and slanderers of the Catholic dogma ${ }^{34}$. In Zanchino Ugolini's treatise De haereticis tractatus aureus (c. 1330), those prerogatives are represented as a matter of self-defense against the infidel threat $^{35}$. The Directorium inquisitorum, by the Catalan (and convert) inquisitor Nicholas Eymerich (1376), offered a clearer systematization of the Jewish offences against the Church, reducing the casuistry to three criminal typologies: proselytes, false converts and blasphemers ${ }^{36}$.

The jurisdictional bulk remained, nevertheless, in the hands of kings and the rest of lay territorial powers. Despite every Christian earthly lord theoretically owing blind loyalty to the Church, their relationship with the Jews was often conditioned by further political considerations, and the Crown of Aragon was not an exception.

Catalan-Aragonese kings proved to be reluctant to implement canonical rules. For example, they often appointed Jewish officials for leading administrative posts, especially during the reigns of James I (1213-1276) and Peter the Great (1276-1285). This openly contravened what had been decreed in Lateran IV. Jewish functionaries were particularly appreciated for the office of batlle, a sort of local or regional royal administrator with some jurisdictional functions (in modern Catalan batlle means mayor). This practice was not abolished until 1283, when a baronial rebellion encouraged by the excommunication of Peter the Great and the threat of a crusading invasion forced the king to accept a number of demands in order to appease the nobility and the Church ${ }^{37}$. And even then, Jews were still unofficially employed to carry out the same functions (Romano 1983). Until the consolidation of an urban, educated Christian social class (towards the end of the thirteenth and first half of the fourteenth centuries), the Jews provided the only opportunity for

\footnotetext{
${ }^{33}$ Processes inquisitionis, translated and edited by Wakefield (1974: 250ff).

${ }^{34}$ Bernard Gui (1886: 35-36, 67-71, 289-292, for exemple). See also Yerushalmi (1970).

${ }^{35}$ Zanchino Ugolini, De haereticis. Rome, 1579, pp. 220-221.

${ }^{36}$ Nicholas Eymerich, Directorium inquisitorum. Rome, 1587, pp, 352-359.

${ }^{37}$ Cort of Barcelona of 1283: Cortes de los antiguos reinos de Aragon y de Valencia y del principado de Cataluña, Tomo 1, Primera parte..
} 
the monarchy to gain full administrative independence from the clergy and escape from its intellectual monopoly.

The triangle composed by monarchy-Jews-Church was complex, voluble and prone to unexpected and contradictory manifestations. The Jews were a royal property and a valuable source of intellectual and monetary resources. They could be taxed without legal ceremonies, exhausting negotiations and difficult concessions. As often noted by Catalan documentation, they were the treasure of the $\mathrm{king}^{38}$. The monarch was the greatest protector of the Jewry, but his commitment was often challenged by the necessity of satisfying the clergy. The royal policy was a juggling act. Also, the Jewish and Ecclesiastical response and coexistence rules were subject to practical considerations, in which their natural animosity could be interrupted by the needs of the moment. This was the case, for example, of a number of Jews from Tarragona who, after having been accused of usury by royal authorities, took refuge in the lands of the bishop ${ }^{39}$. Hence, the interactions of the Jewry with Christian powers were far from monistic, a situation that probably hampered the Jewish reaction to the rising hostility of the Church and the plebians.

In the Decretales, Penyafort adopted the following view, as summarized by Watt (1992: 96):

Jews and the practice of Judaism are to be protected from abuse by Christians; Christians and Christianity are to be protected from abuse by Jews; Jewish converts to Christianity are to be protected from abuse by both Christians and Jews.

Apparently, the solution, based again on Augustin, was equity and fairness, i.e. justice. Penyafort constructed the canon theory on the concept of justice, and he applied it in a nuanced way to economics and warfare (just price, just war). Interest could be acceptable per accidens; war could be legitimised per persona, objectum, causa, intentio, auctoritas (Valls i Taberner 1996: 229ff). He set the conditions for the acceptability of lending and of making war. But in both cases, he first set the difference between Christians, on the one side, and Muslims and Hebrews, on the other. Justice and the will to comply with agreements should stand in the middle, in a kind of universal balance. But first and for all, conversion should also stand above the framework as the ultimate end of all actions. As the first anonymous fourteenth-centuries Lullius' biographer put it in the Vita Coetanea, the notion of crusade was giving way to the idea of mission: Pro quorum conversion procuranda totus erat caritatis incendiis inflammatus. ${ }^{40}$ This also was the sense and metaphor of the Christian integration - a blazing, burning flame. To achieve this purpose all means could be used.

The flame of the faith consumed all kinds of cultural knowledge - cultural, social, political, philosophical and theological. The Mendicant Orders turned Arabic and Hebrew texts into interpretable goods for their own consumption. Ramon Llull, Lullius, adopted another strategy. He extended the baton of faith a little further. Even today, his ars combinatoria remains interesting and difficult to analyse. So was his attitude. He took seriously Hebrew and Arabic philosophy without manipulating it and he dissociated himself from Scholastics. He especially disliked Dominican

\footnotetext{
${ }^{38}$ On the status of the Jews, see Assis (2008: 9-18).

${ }^{39}$ ACA, Cartes Reals [Royal Letters], Jaime II, c. 114, n 500.

${ }^{40}$ Anonymus, Vita Raimundi Lulli, Opera Latina, ed. Balme / Paba n, Raymundiana (Anm. 6), 33-32, p. 19 as quoted at length by Tischler 2019 .
} 
methods and had no interest in Ramon Martí's works, who exerted a direct influence on other Catalan thinkers such as Arnau de Vilanova and Francesc Eiximenis (Fidora 2012). Dominican policy became official Church dogma. According to it, certain things such as the Trinity, the Incarnation or the creation of the world can only be known through revelation and are unprovable by rational means. Llull opposed this notion, for as if there was not some way to prove the Trinity and the Incarnation by other means, Muslims and Jews would never be convinced (Bonner 1990). It is worth noting here that this is why Pope Gregory XI condemned Llull and Lullism in 1376.

However, his mission - a notion he received personally from Penyafort - remained the same: obtaining as many conversions as possible. But by other means. Penyafort commissioned Llull to start training centres to evangelize the Muslim world in Majorca. He devoted his entire life and philosophy to this movement.

Lull is a major and original thinker, whose works in Catalan, Latin, French and Arabic, have never been out of print. We are interested in mentioning him here, first, because of his notion of interreligious dialogue; second, because there is an active debate about his Jewish influences. Some of his technical work shows, beyond Greek and Arabic philosophy, a direct knowledge of the early mystic Kabbalah in Catalonia. His ontology, logic and idea of rationality are all connected to the notion of God, and this links to the way he understood Godhead. Kabbalah resonates, but only resonates, into it.

One of the first scholars to advocate for the direct influence of Kabbalah on Llull was J.M. Millàs Vallicrosa (1958). Millàs realised that the essence of the ten Sefirot were mainly coincident with the nine Dignities of the first Lullian circle: Bonitas, Magnitudo, Aeternitas seu Duratio, Potestas, Sapientia, Volun tas, Virtus, Veritas and Gloria. Harvey Hames strongly asserts such an influence. We can discuss whether these are to be interpreted as principles, axioms or attributes. Why Llull specifically chose them over other possibilities has not yet been resolved. His truth-finding procedure (ars inveniendi in Latin, art de trobar veritat, in Catalan) formalised binary and ternary relations and used (and figured out for the first time) several logical techniques - e.g. the argument from equivalence (per equiparantiam) — to support the processing. ${ }^{41}$ But what we would like to highlight here is not the practical use of the art through logical and rhetorical means, but the practical syllogism that underlies his whole intention. As noticed by many scholars, his religious belief, the conversion of the "infidels" ranked first (Colomer 1995; Ruiz Simon 1997; Crossley 2005).

Philosopher and former Wittgenstein's student G. Henrik von Wright, following Aristotle and the revival of his tradition after WWII, called the means to an end reasoning 'practical inference' (von Wright 1963). This kind of inferences are not logically conclusive and relate intention and actions. He studied many variants in the third and first persons with a deontic conclusion:

[5] $\mathrm{X}$ intends to make it true that $\mathrm{E}$

Unless does A, he (i.e. X) will not achieve this

Therefore, Y must do A wants to attain x (Wright 1963: 41)

[6] I intend to make it true that $\mathrm{E}$

Unless I do A, I shall not achieve this

\footnotetext{
${ }^{41}$ On the post-Art period and the logical techniques, see Bonner (2012: 211ff).
} 


\section{Therefore, I must do A}

(von Wright 1972)

Von Wright qualified [5] as practical necessity: "the necessity of doing something under which an agent is, if he is to attain some end of his own" (Wright 1972: 43). He also observed that in a practical inference in the first person [6] where the second premise is false, it may still be the case that 'I' believes it (mistakenly) true, and then it will be valid for him: "this is a peculiarity of a practical inference in the first person" (von Wright 1972: 44).

At first sight, [5] and [6] could be applied to describe Llull's reasoning. It would not be wrong, as the action is triggered by the necessity to obtain the goal. He distinguishes first (goals) and second (means) intention (Soler 2017). However, a closer look shows that we should turn towards a dialectic argument to endorse the speaker's position, i.e. an argument in which both agents display their opponent in the premises. [7] would be an attempt to capture the situation:

[7] Faith can be reached rationally

The Art displays all rational arguments

You must convert

From a pragmatic point of view, inside out, the conclusion is in fact assumed as a first premise: it is not the case that I infer that you must convert, because this is the explicit and most important aim of the whole discussion. 'You must convert' is the case. Under a prescriptive form (an imperative, a command), the first premise can also be transformed into a deontic assumption: 'it is the case that you must convert'. The final generalization is an inductive conclusion reached through a middle ground argument about the foundation of rationality. But it is naturally inferred from the first prescription, which is deemed to be the self-evident truth from which the speaker is departing:

[8] You must convert

The Art displays all rational arguments

Faith can be reached rationally

Llull's notion of dialogue is certainly not based on the Scholastic tradition. It displays the tactic of leaving the initiative to the opponent: test it, the Art will 'demonstrate' rationally the veracity of Christian faith. There is a difference between seeking for true conversions as a rational act and imposing the Christian faith at any cost. But the situation depicted by [8] is not a symmetric situation either. It entails already an imposition with a certain degree of violence that can escalate. When applied, it advances in time and escalates in intensity: Jews are not deemed to be witnesses any more, but justiciables, as there is an implicit judgement in [8] that Llull made explicit many times. There are necessary reasons that demonstrate the truth and superiority of the Christian faith. The unity of a Christian faith, a Christian doctrine, a Christian science, lies in his credere per intelligere, as he put it in El llibre del gentil e dels tres savis (1272-74). ${ }^{42}$ According to him, this also holds for Christians themselves, who were not living up to their commitment with their own faith.

\footnotetext{
42 “credere pro credere, sed credere pro intelligere”, cfr. Domínguez (1987).
} 


\section{CONCLUSIONS AND FURTHER WORK}

In this paper we have discussed imprints, traditions, violence and dialogue between Catholics and Jews in medieval Catalonia. The medieval mind was, to a large extent, a result of attempts to conjugate and rationalize traditions, violence and dialogue. The Late Middle Ages was a period in which an almost childish enthusiasm was combined with the coldest rationalism. Idiosyncrasies, hopes, philias and aversions relied on intellectual matrices where social, religious and political dimensions cohesively converged. Nothing was casual. Spirituality was the ultimate resort that embraced everything, the seminal tie. The medieval legacy, whatever its manifestations, can only be understood in light of those premises.

We started by referring to the case of Jewish mysticism as a social phenomenon and as a response against suffering. Kabbalah emerged in a moment in which the rising anti-Jewish hostility was turning into a real and noticeable threat. The myth of the Shevirat ha-Kelim for example, became a referential point when violence and pain appeared to push the limits of rationality, such as in the Holocaust. The confrontation between good and evil (which is no more than a deformation of divine goodness) and the close relationship between pious men and God, to whom they might return, constituted a narration of hope and strength.

Literature is another door to the personal and collective impact of tragedy and persecution. The poems by Iṣhaq Sheshet Perfet and Mosheh Remos we quoted, show how the Catalan Jews tried to cope with an incomprehensible but unescapable brutality. Their verses express desperation and horror, but also resilience and determination.

Our major aim has been the study of the gestation of the hostility that prompted this mystical response and led to the massacres of 1391 — among many others. Its origins have been found in a tension between hatred and dialogue or, more precisely, in the impossibility of dialogue. The rise of the Scholastics challenged the traditional approaches to Augustine and his claims for tolerance. Despite his theses having advocated for the physical protection of the Jews and a proselytizing model based on love and arguments, they set the grounds for marginalization and religious hate. The emergence of the mendicant orders, the fight against heretical movements and the incorporation of Aristotelian logic revitalized the missionizing zeal of the Church and molded a new sense of spiritual and political Christian unity. The Jews started to be perceived as an internal enemy that challenged the unicity of Christendom.

The new apologetic movements resulting from this process departed from the assumption that the Jews were mistaken; thus, their errors could be demonstrated through reason. If the truth was logically proved and despite this they persevered in their false beliefs, they would not only have erred, but would be evil and perfidious, a threat that should be physically eradicated.

Public disputations between rabbis and friars became the elementary tool in order to pursue this goal. However, the conception of those debates and the syllogistic argumentation by the Christian side virtually precluded dialogue on equal terms. The friars were always in a position of political power that contrasted with the delicate and dangerous situation of the Jewish spokesmen. The Christian arguments were considered true and irrefutable beforehand, while the counterpart was mistaken by default. The rabbis had no chance to defend their arguments. Our use of modern 
theories of discourse analysis and informal logic to the study of medieval disputations gives evidence of these limitations.

The disputation of Barcelona, on which we have focused at length, is paradigmatic. It was organized as a political event by the highest spiritual and lay authorities in the Crown of Aragon. Nahmanides had to moderate his argumentation on behalf of his life and the security of the Catalan communities. Although he was allowed to freely present his points, he had to flee from the Crown after the debate. This example also evinces that the elementary metaphysical and logical approaches to theology of both sides were irreconcilable, which also hampered mutual understanding in purely philosophical terms.

The political and theological evolution of the Church since the $12^{\text {th }} \mathrm{c}$., including its consequences for the Jewish population, was also reflected in the construction of Catalan society. Catalonia had always been a land of dialogue and violence. The absence of political actors who could monopolize power and authority resulted in a constant necessity of reaching agreements. Not even the king was capable of enforcing his will by force.

We drew a simple matrix - a matrix of conflict and dialogue - to mark the escalation of violence and its intensity over time. This should be developed a bit more and be populated with data. The Catalan matrix is in fact a double matrix. The four quadrants could have been ordered around the two axes of power (juridictio) and covenant (pactum) that organise the structure of old Catalan public law. We did not attempt to carry this out in the present article. It is the subject matter for a follow-up article.

There is a growing literature on the persistence of cultural traits in continuity flows to explain the persistence and survival of antisemitism in some places more than others. Starting from the Black Death in 1348-50, Voigtländer and Voth (2012) have used plague-era pogroms in ninehundred German cities as an indicator for medieval anti-Semitism. They contend "that the same places that witnessed violent attacks on Jews during the plague in 1349 also showed more antiSemitic attitudes more than half a millennium later: their inhabitants engaged in more antiSemitic violence in the 1920s" (Voigtländer and Voth 2012: 1385). Tolerance and hatred of Jews has persisted at the local level in a consistent way over six-hundred years. At a normative sociocultural level, the existence of long-term flows can be explained.

Likewise, at an intellectual level the persistence of some argumentation schemes and cultural (or folk) models through philosophies and educational institutions (such as universities) can and should be described and explained. The emergence and appearance of knowledge is never neutral. Authors correctly refer sometimes to their intellectual heritage when they quote their precedents and genealogies of thought. They explicitly go back to Plato, Aristotle, Paul or Augustin. However, sometimes, quotes, citations, and the roots of thinking are also blurred. Authors protect themselves from persecution not directly quoting their real sources and even hiding or enveloping their ideas into other more palatable forms. Leo Strauss convincingly showed that this was the case with Maimonides, Spinoza and many other thinkers of the Jewish tradition. They mastered the art of "writing between the lines", as writing and thinking were dangerous activities (Cf. Strauss 1988). 
Persistence and transmission also relate to the art of translation and the building of libraries and repositories (and now, in the digital era, metadata and ontologies). Authors might not recognise the origins of the arguments they are using. This is also related to the way traditions are shaped. Carl Schmitt, for instance, an influent anti-Semitic jurist and political thinker, referred to mediaeval monarchies and the development of what he called the Ius Publicum Europeum. He never referred to Ramon Martí and the Dominican Catalan tradition he was undoubtedly replicating. He knew it through the Canonists, Thomas Aquinas, the $16^{\text {th }}$ c. Spanish Second Scholastics, and lately, through the $19^{\text {th }}$ c.. thinker Donoso Cortés, a political thinker who repeated many of the theological arguments of the Counter-reformation against the heresies. However, we might consistently find the components of the matrix in the Schmittian notions of complexio oppositorum and political theology. This research will have to wait for another occasion.

\section{BIBLIOGRAPHY}

Abulafia, A. S. 1998. Christians and Jews in Dispute: Disputational Literature and the Rise of anti-Judaism in the West (c. 1000-1150). Farham: Ashgate Publishing.

Abulafia, A. S. (ed.). 2001. Religious violence between Christians and Jews: medieval roots, modern perspectives. Dordrecht: Springer.

Alturo, J., Bellès, J., Fonts i Rius, J. Mª., García, Y. and Mundó, A. M. (ed.). 2003. Liber iudicum popularis. Barcelona: Generalitat de Catalunya, Departament de Justícia i Interior.

Anonymus. Vita Raimundi Lulli, Opera Latina. Ed. Balme / Paban, Raymundiana (Anm. 6).

Assis, Y. T. 2008. The Golden Age of Aragonese Jewry. London: The Littman Library of Jewish Civilization.

Augustin of Hippo. 1955. "Tractatus Adversus Judaeos". In Treatises on Marriage and Other Subjects, Fathers of the Church (vol. 27). Eds. Roy J. Deferrari. Washington: Catholic University of America Press, pp. 387-417. Accessible at Roger Pearse's blog: https://www.rogerpearse.com/weblog/2015/06/11/augustines-treatise-against-the-jews/

Augustine. 1995. De Doctrina Christiana. Oxford: Clarendon Press.

Augustine of Hippo. 1890. City of God. New York: The Christian Literature Publishing Co.

Backman, C. R. 1990. “Arnau de Vilanova and the Franciscan Spirituals in Sicily”. Franciscan Studies, 50: 3-29.

Backman C. R. 2000. "Arnau de Vilanova and the Body at the End of the World". In Last Things. Death and the Apocalypse in the Middle Ages. Eds. Caroline Walker Bynum and Paul Freedman. Philadelphia: University of Pennsylvania Press, pp. 140-155.

Baer, Y. A. 2001. History of the Jews in Christian Spain. Skokie (Illinois): Varda Books.

Baron, S. W. 1942. The Jewish Community: Its History and Structure to the American Revolution (Vol. 1). Philadelphia: Jewish Publication Society of America, 1942.

Bernard Gui. 1866. Practica inquisitionis heretice pravitatis. Paris: Alphonse Picard. 
Bonner, A. 1989. "L'apologètica de Ramon Martí i Ramon Llull davant de l'Islam i del judaisme". Estudi General, 9: 171-185.

Bonner, A. 1990. "Ramon Llull and the Dominicans". Catalan Review, 4 (1-2): 77-392.

Bonner, A. 2012. L'Art i la lògica de Ramon Llull. Manual d'ús. Barcelona: Universitat de Barcelona and Universitat de les Illes Balears.

Brentjes, S., Fidora, A. and Tischler, M. M. 2014. "Towards a New Approach to Medieval CrossCultural Exchanges". Journal of Transcultural Medieval Studies, 1 (1): 9-50

Caputo, N. 2007. Nahmanides in Medieval Catalonia: History, Community and Messianism. Notre Dame (Indiana): University of Notre Dame Press, 2007.

Careil, L. A. 1861. Leibniz, la philosophie juive et la Cabale: Trois lectures à l'Académie des sciences morales et politiques avec les manuscrits inédits de Leibniz. Paris: Durand.

Carreras i Artau, T. 1949. "“La "allocutio super tetragrammaton" de Arnaldo de Vilanova”. Sefarad, 9 (1): 75-105.

Casanovas, P. 2019. "Catalan Identities: Language, Power and Political Pactism from a Historical Perspective". In The Rise of Catalan Identity: Social Commitment and Political Engagement in the Twentieth Century. Eds., Pompeu Casanovas, Montserrat Corretger and Vicent Salvador. Cham: Springer, pp. 19-48.

Cecini, U. and de la Cruz Palma, O. (eds.). 2018. Extractiones de Talmud. Turnhout: Corpus Christianorum, Brepols Publishers.

Chazan, R. 1989. Daggers of Faith: Thirteenth-Century Christian Missionizing and Jewish Response. Los Angeles and Berkeley: University of California Press.

Chazan, R. 1992. Barcelona and Beyond: The Disputation of 1263 and its Aftermath. Los Angeles and Berkeley: University of California Press.

Cohen, J. 1983. "The Jews as the Killers of Christ in the Latin Tradition, from Augustine to the Friars". Traditio, 39: 1-27.

Cohen, J. 1984. The Friars and the Jews: the Evolution of Medieval anti-Judaism. Ithaca (NY): Cornell University Press.

Cohen, J. 1992. "Toward a Functional Classification of Jewish anti-Christian Polemic in the High Middle-Ages". In Religionsgespräche im Mittelalter. Eds. Bernard Lewis, Friedrich Niewohner and Friedrich N. Harrassowitz, Wiesbadn: Wolfenbütteler Mittelalter-Studien, pp. 93-114.

Cole, P. 2007. The Dream of the Poem. Hebrew Poetry from Muslim and Christian Spain 9501452. Princeton: Princeton University Press.

Colomer, E. 1995. "El Arte luliana y la moderna informática”. Catalònia, 43: 20-23.

Consilium Lateranense IV (1215) in http://www.internetsv.info/Lateranense4.html 
1896. Cortes de los antiguos reinos de Aragon y de Valencia y del principado de Cataluña, Tomo 1, Primera parte. Madrid: Real Academia de la Historia.

Crossley, J. N. 2005. "Raymond Llull's contributions to computer science". In Ramon Llull: From the Ars Magna to Artificial Intelligence. Eds. Alexander Fidora and Carles Sierra. Barcelona: CSIC, pp. 39-59

Dan, J. 1985. “Gershom Scholem's Reconstruction of Early Kabbalah”. Modern Judaism, 5 (1): 39-66.

Decretals of Gregory IX http://www.canonlaw.info/canonlaw_IUSDECR.htm

Doménech, J. L. et al. 2018. "Dialectical logic for mythical and mystical superstructural systems". Kybernetes 48 (8): 1653-1680.

Domínguez, F. 1987. “Idea y estructura de la Vita Raymundi Lulii”. Estudios Lulianos, 27: 1-20.

Elazar, D. 1977. "The Kehillah". Workshop in the Covenant Idea and the Jewish Political Tradition, Bar-Ilan University, Working Paper n. 6.

Ferro, V. 1987. El dret public català. Les iastitucions a Catalunya fins al Decret de Nova Planta. Vic: Eumo Editorial.

Fidora, A. 2012. "Ramon Martí in context: The Influence of the" Pugio Fidei" on Ramon Llull, Arnau de Vilanova and Francesc Eiximenis". Recherches de Théologie et Philosophie médiévales, 79 (2): 373-397.

Fidora, A. and Hasselhoff, G. K. (eds.). 2019. The Talmud in Dispute During the High Middle Ages. Bellaterra: Servei de Publicacions de la Universitat Autónoma de Barcelona.

Freeman, G. 1981. "The Rabbinic Understanding of Covenant as a Political Idea". In Kinship and Consent: The Jewish Political Tradition and its Contemporary Uses. Ed. Daniel Elazar. Ramat Gan: Turtledove Publishing, pp. 59-86.

Funkenstein, A. 1993. Perceptions of Jewish History. Los Angeles and Berkeley: University of California Press.

Gampel, B. R. 2016. Anti-Jewish Riots in the Crown of Aragon. Cambridge: Cambridge University Press.

Gigerenzer, G. 2008. "Moral intuition= fast and frugal heuristics?”. In Moral Psychology (Vol. 2): The cognitive science of morality: Intuition and diversity. Eds. Walter Sinnott-Armstrong. Cambridge (Mass.): MIT Press, pp. 1-26.

Gonzalvo i Bou, G. 1996. "Els jueus i els Usatges de Barcelona”. Barcelona: Quaderns d'Història, 23: $117-124$.

Greenberg, G. 1996. "Nineteenth Century Jewish Thought as Shevirat Ha-Kelim". In Jewish Philosophy and the Academy. Ed. Emil L. Fackenheim and Raphael Jospe. Madison and Teaneck: Dickinson University Press, pp. 100-114 
Hames, H. J. 2007. Like Angels on Jacob's Ladder. Abraham Abulafia, the Franciscans and Joachimism. Albany: State University of New York Press.

Hershman, A. M. 1943. Rabbi Isaac ben Sheshet Perfet and His Times. New York: The Jewish Theological Seminary of America.

Idel, M. 1988. Kabbalah: New Perspectives. New Heaven: Yale University Press.

Krueger, P. (ed.). 1892. Corpus Iuris Civilis. Berlin: Weidmannos.

Lewis, C. S. 1964. The Discarded Image. Cambridge: Cambridge University Press.

Limor, O. 2010. "Polemical varieties: Religious disputations in 13th century Spain". Iberia Judai$c a, 2: 55-79$.

Llewellyn, B. (2004). They Who Give from Evil: The Response of the Eastern Church to Moneylending in the Early Christian Era. Toronto: Thesis submitted to the Faculty of Theology at the University of St. Michael's Collegeand the Department of History of the Toronto School of Theology.

Löwith, K. 1949. Meaning in History. Chicago and London: The University of Chicago Press.

Martí, J. P. and Llopis Estampers J. (eds). 1973. Constitutions y altres drets de Cathalunya. Barcelona: Editorial Basa.

Maspons i Anglasell, F. P. 1932. L'esperit del dret públic català. Barcelona: Barcino.

Millàs Vallicrosa, J. Ma. 1940. La poesía sagrada hebraicoespañola. Madrid: CSIC.

Millàs Vallicrosa, J. Ma . 1958. “Algunas relaciones entre la doctrina luliana y la Cábala”. Sefarad, 18 (2): 241-253.

Montagut i Estragués, T. de. 1989. "Pactisme o absolutisme a Catalunya: les grans institucions de govern (s. XV-XVI)". Anuario de Estudios Medievales, 19: 669-679.

Moore, G. F. 1921. “Christian writers on Judaism”. Harvard Theological Review, 14 (3): 197-254.

(Mosheh ben Nạ̣man). 1964. "ספה בן נשמאן ("The Book of Redemption”). In

כתבי רבינו משה בן נחמן (Writings of Moshe ben Nahman). Ed. Charles ben Chaver. Jerusalem: Mosad ha-Rav Kuk, 1964.

Muntané i Santiveri, J.X. 2014. "Anàlisi de l'estructura del jurament de les malediccions dels jueus catalans: usatge 171”. Revista de Dret Històric Català, 13: 9-48.

Nahmanide, Rabbi Moïse ben Nahman. 1984. La dispute de Barcelone. Lagrasse: Verdier.

Nicholas Eymerich. 1587. Directorium inquisitorum. Rome.

Nirenberg, D. 2002."Conversion, sex, and segregation: Jews and Christians in medieval Spain". American Historical Review 107, 4: 1065-1093.

Nirenberg, D. 2007. "Une société face à l'altérité”. In Annales. Histoire, Sciences Sociales 62 (4) : 755-790. 
Nirenberg, D. 2015. Communities of violence: Persecution of minorities in the Middle Ages. Princeton: Princeton University Press.

Palos, J.-L. 1995. "Estrategias de control y limitaciones del poder real en los siglos XVI-XVII". Manuscrits. Revista d'Història Moderna, 13: 143-154.

Processes inquisitionis, translated and edited in Wakefield, W. 1974. Heresy, Crusade and Inquisition in Southern Frace, 1100-1250. Berkeley and Los Angeles: University of California Press, pp. $250 \mathrm{ff}$.

Raimundo de Penyafort. 1945. Summa Iuris. Barcelona: Universidad de Barcelona.

Ramban [Nahmanides]. 2004. The Torah: with Ramban's Commentary Translated, Annotated and Elucidated (Vol. 1, Genesis). New York: Mesorah Publications (English and Hebrew).

שלות ותשבות . שבב"א (Rashba [Shlomo ben Adert]). 1997 רשבא (Responsa). Jerusalem: Makon Aor haMizrah.

Raymundi Martini. 1651. Pugio fidei adversus mauros, et iudaeos. Paris.

Reed, C. and Walton, D. 2001. "Applications of argumentation schemes". University of Windsor, OSSA 4.

Riera i Sans, J. 1986a. "El Baptisme de Rabí Ishaq ben Seset Perfet”. Calls, 1: 43-52.

Riera i Sans, J. 1986b. "Estudis sobre el judaisme catala. Anys 1970-1984”. Calls [Tàrrega], 1: 93-132.

Riera i Sans, J. 1987. "Estudis sobre el judaisme catala. Anys 1929-1969". Calls [Tàrrega], 2: 181209.

Riera i Sans, J. 2014. "Moixè ben Nahman, Bonastruc de Porta". Tamid: Revista Catalana Anual d'Estudis Hebraics, 10 (2014): 7-33.

Ripoll Sastre, P. 2018. Llibre dels vuit senyals (15th century): An Edition, Legal and Comparative Study. Doctoral Dissertation. Barcelona: Universitat Pompeu Fabra.

Romano, D. 1983. Judíos al servicio de Pedro el Grande de Aragón: 1276-1285. Barcelona : Universidad de Barcelona.

Roth, N. 2011. “1391 in Aragón, Catalonia, Valencia and Majorca”. Iberia Judaica, 3: 49-75.

Ruiz Simon, J. Ma . 1997. L'Art de Ramon Llull i la teoria escolàstica de la ciencia. Doctoral dissertation, Universitat Autònoma de Barcelona.

Salrach i Marés, J. M. 1989. "La Pesta Negra i els orígens del problema remença". In Pere el Cerimoniós i la seva època. Barcelona : Consell Superior d'Investigacions Científiques, pp. 13-34.

חיים שירמן (Schirmann, H). 1954-1956. השירה העברית בספרד ובפרובאנס (Hebrew Poetry from Sefarad and Provence). Jerusalem: Mosad Byalik.

Scholem, G. 1941. "The Zohar. I. The Book and its Author". In Major Trends in Jewish Mysticism. Ed. Gershom Scholem. Jerusalem: Schocken Publishing House. 
Sholem, G. 1971. "Devekut or Communion with God". In The Messianic Idea in Judaism, and Other Essays on Jewish Spirituality. Ed. Gershom Sholem. New York: Shoken Books, pp. 203227.

Scholem, G. 1987. Origins of the Kabbalah. Princeton: Princeton University Press.

Sierra, C (ed.). 2011. Ramon Llull: From the Ars Magna to Artificial Intelligence. Barcelona: Artificial Intelligence Research Institute.

Soler, A. 2017. "Ramon Llull: escriptura, lectura i reordenació del món”. Setè centenari de Ramon Llull: el projecte missional i la pervivència de la devoció: actes del congrés d'obertura de l'Any Llull (Palma 24-27 de novembre de 2015), Universitat de Barcelona, pp. 317-337.

Stow, K. R. 1981. "Papal and royal attitudes toward Jewish lending in the thirteenth century". AJS Review, 6: 161-162.

Strauss, L. 1988. Persecution and the Art of Writing (1952). Reissued Chicago: University of Chicago Press.

1703. Summa Sti Raymundi di Penniafort, Barcinonensis, Ord. Praedeicator, de Poenitentia et Matrimonio, cum Glossis Ioannis de Friburgo. Roma, Ioannis Tallini.

Sysyn, F. 1992. "The Khmelnytsky Uprising and Ukrainian Nation-Building”. Journal of Ukranian Studies, 17 (1-2): 141-170.

Szpiech, R. W. 2011. "Arabic Citations in Hebrew Characters in the Pugio Fidei of Dominican Raymond Martini: Between Authenticity and Authority”, Al-Qantara, 32 (1): 71-107.

Szpiech, R. W. 2014. "The Aura of an Alphabet: Interpreting the Hebrew Gospels in Ramon Martí’s Dagger of Faith (1278)”. Numen, 61 (4): 334-363.

Szpiech, R. 2016. "Translation, transcription, and transliteration in the polemics of Raymond Martini”. In Translating the Middle Ages. Eds. Karen L. Fresco and Charles D. Wright. Ashgate: Routledge, pp. 171-187.

Tartakoff, P. 2012. Between Christian and Jew: Conversion and Inquisition in the Crown of Aragon, 1250-1391. Philadelphia: University of Pennsylvania Press.

Taubes, J. 2009. Occidental Eschatology. Stanford: Stanford University Press.

Taubes, J. 2013. To Carl Schmitt. Letters and Reflections. New York: Columbia University Press.

Tischler, M. M. 2019. "Die Dominikanermission unter den Muslimen im 13. Jahrhundert: Warum der mallorquinische Laie, Universalgelehrte und Missionar Ramon Llull zum Fundamentalkritiker des Dominikanerordens wurde." Zeitschrift für Missionswissenschaft und Religionswissenschaft 103 (1/2): 34-52.

Twersky, I. 1983. "'Open Rebuke and Concealed Love': Nahmanides and the Andalusian tradition”. In Rabbi Moses Nahmanides (Ramban): Explorations in His Religious and Literary Virtuosity. Ed. Isadore Twersky. Cambridge (Massachusetts): Harvard University Press, pp. 11-34. 
Vajda, G. 1963. "Recherches récentes sur l'ésotérisme juif: II (1954-1962) (Suite)". Revue de l'histoire des religions, 165 (1): 49-78.

Vajda, G., 1977. "Recherches récentes sur l'ésotérisme juif (Troisième série, années 1963-1975) (suite)". Revue de l'histoire des religions, 192 (2): 165-198.

Valls i Taberner, F. 1996. Sant Ramon de Penyafort. Barcelona: La Formiga d'Or.

Voigtländer, N. and Voth, H.J. 2012. "Persecution perpetuated: the medieval origins of antiSemitic violence in Nazi Germany". The Quarterly Journal of Economics, 127 (3): 1339-1392.

Walton, D. 1996. Argumentation Schemes for Presumptive Reasoning. Mahwah. N.J.: Lawrence Erlbaum Associates.

Walton, D. 2013. Scare tactics: Arguments that appeal to fear and threats (Vol. 3). Dordrecht: Springer Science \& Business Media.

Walton, D. 2014. "A dialectical analysis of the ad baculum fallacy". Informal Logic 34 (3): 276310.

Watt, J. A. 1992. "Jews and Christians in the Gregorian Decretals". Studies in Church History 29: 93-105.

Wolfson, E. R. 1989. "By Way of Truth: Aspects of Naḥmanides' Kabbalistic Hermeneutic”. AJS Review, 14 (2): 103-178.

Wright, G. H. Von. 1963. "Practical inference.". The philosophical review, 72 (2): 159-179.

Wright, G. H. Von. 1972. “On so-called practical inference”. Acta sociològica, 15 (1): 39-53.

Yerushalmi, H. Y. 1970. "The Inquisition and the Jews of France in the Time of Bernard Gui". The Harvard Theological Review, 63 (3): 317-376.

Zanchino U. 1579. De haereticis. Rome. 